ISSN:2528-9527

E-ISSN: 2528-9535

Yıl Year: 11

Cilt Volume: 18

Sayı Issue: 39

Temmuz July 2021

\title{
Towards Transformation of Communication Strategy in Dealing with Russian Propaganda
}

DOI: 10.26466/opus.783555

\author{
$*$ \\ Eduard Melnikau* \\ ${ }^{*}$ Prof., European Humanities University, Lithuania \\ E-Mail: eduard.melnikau@ehu.lt \\ ORCID: $\quad$ 0000-0002-6536-9971
}

\begin{abstract}
The article claims that there are other no less effective than purely "military" methods of successful opposing Putin's propaganda both in Russia and abroad and aims at providing alternative approach towards organizing mass communication systems designed to change the situation both in Russia and the whole post-Soviet area. The article starts with the analysis of the transformation of "Soviet idea" into "Russian idea" and the KGB concept "active measures". Then specifics of modern Russian media and its role in "hybrid warfare" are revealed. Finally, possible approaches in dealing with Russian propaganda are discussed. Authors conclude that stereotypes of Putin's propaganda cannot be eradicated by purely "military", "counter-propaganda" methods. Instead, it is necessary to break the vicious identity of both Russian mentality and Russian government. This can be done only by presenting the reality of Russian life through live examples, personal experience as well as by the development of constructive psychological stereotypes.
\end{abstract}

Keywords: $\quad$ Russian idea, Putin's propaganda, hybrid warfare, active measures. 
ISSN:2528-9527

E-ISSN: 2528-9535

YIl Year: 11

Cilt Volume: 18

Sayı Issue: 39

Uluslararası Toplum Araştırmaları Dergisi International Journal of Society Researches

Temmuz July 2021

Makalenin Geliss Tarihi Received Date: 12/06/2019 Makalenin Kabul Tarihi Accepted Date: 08/01/2021

\section{Rus Propagandasıyla Mücadelede İletişim Stratejisinin Dönüşümüne Doğru}

Öz

Bu makale hem Rusya'da hem de yurtdışında Putin' in propagandasına karşı başarıl bir şekilde "askeri" yöntemlerden daha az etkili olmayan başka yöntemler olduğunu iddia etmekte ve Sovyet bölgesinde hem Rusya'daki durumu hem de olası Rusya sonrası durumu değiş̧irmek için tasarlanmış kitle iletişim sistemlerini organize etmeye alternatif bir yaklaşım sağlamayı hedefliyor. Ayrıca makale, "Sovyet fikrinin" "Rus fikrine" dönüşümünün ve KGB kavramının "aktif önlemler"in analiziyle başlarken sonrası için de öngörüler ve kestirimler içermektedir. Ardından modern Rus medyasının özellikleri ve "hibrit savaş"taki rolünü ortaya çıkarmak amacıyla yeni bir yaklaşımı ortaya koymaya çalışmaktadır. Son olarak, Rus propagandasıyla ilgili olası yaklaşımlar tartışlarak analitik bir çözümleme yapma çabası gerçekleştirilmiştir. Yazar, Putin'in propagandasının klişelerinin tamamen "askeri", "karşı propaganda" yöntemlerle ortadan kaldırllamayacağ $ı$ sonucuna varırken yapilan analiz sonrasinda bunun yerine hem Rus zihniyetinin hem de Rus hükümetinin kısır kimliğini kırmak gerekliliğinin altın çizmiştir. Bu, ancak Rus yaşamının gerçekliğini canlı örnekler, kişisel deneyimler ve yapıcı psikolojik stereotiplerin geliştirilmesi yoluyla sunarak yapılabilir.

Anahtar Kelimeler: Rus fikri, Putin'in propagandası, hibrit savaş, aktif önlemler. 


\section{Introduction}

Western analysts observe recent transformations of the concept "hybrid warfare" in the context of Russian-Ukrainian relationship when the focus has shifted from a direct hostility and secret operations to efforts aimed at changing the consciousness of public via aggressive programs of disinformation (Paul and Matthews 2016; Veebel and Markus 2016; Aktas 2017; Chadwick 2017; Zollmann 2019). This fact indicates the growing role of the factor of mass information and encourages us to (re)think about priorities, strategies and tactics of communication under changed conditions as well as about their final results. A comprehensive plan to counteract Russian propaganda that outlines short, medium, and longterm measures leading to general restructuring of the Western media in provided in the Center for European Policy Analysis (CEPA) report "Winning the Information War Redux Techniques and Counterstrategies to Russian Propaganda in Central and Eastern Europe Extended and Revised Edition. Techniques and Counterstrategies to Russian Propaganda in Central and Eastern Europe" (Center 2017). However, it is necessary to consider the need to develop new areas of work with Russian-speaking as well as foreign audiences.

So far, we can observe direct opposition to the diverse methods of so called Putin's propaganda (Oates 2016; Abrams 2016; Van Herpen 2016). However, we believe that this strategy might be insufficient and therefore, it is important to switch from "defensive" strategies and direct confrontation to more varied, diverse strategies and tactics that would take into account: a) specifics of the local political situation in Russia; b) the origins of the "effectiveness" of Putin's propaganda, which is largely based on the specifics of the mentality of the population; c) content and forms of communication messages; d) ways of delivering of content to a mass audience.

Some of these aspects have already been addressed by numerous authors. P. M. Nagy (2000) focuses on the economic and social aspects of the Russian state. He also defines nine most important sectors (areas) in which its collapse develops. There is a communication component in each of these sectors that slows down these processes and contributes to the stabilization of the Putin regime or in other words, the stagnation of all 
socio-political processes. G. Sussman (2011) notices that the Putin's regime simply took advantage of the post-industrial and information society, being neither one nor the other. Based on case studies, S. Oates (2016) shows that Russian elites demonstrate their ability to adapt to growing problems and use many aspects of communication to strengthen information dominance over citizens. A solid empirical material for building new conceptual approaches is provided by J. Dougherty (2015). Author emphasizes the importance of Putin's bi-directional ("twopronged") propaganda strategy inside and outside Russia. Inside Russia, alternative communications are suppressed and pushed out. At the same time, the cutting-edge information technologies that are deployed outside Russia at its scope resemble the state policy. The Kremlin's goal is to destroy the Western monopoly on the "truth". It seems that Russian authorities are convinced that information is the main weapon of the $21^{\text {st }}$ century, and they can own this weapon no less effectively than its opponents.

S. Abrams (2016) observes that many methods of today's Putin propaganda are taken from the arsenal of Soviet "active measures" and therefore, the author suggests rethinking the rich historical experience of the West's opposition to Soviet propaganda considering today's realities. C. Paul and M. Matthews (2016) revealed the connection between the current methods of Kremlin propaganda and ones of political advertising well-known in the USA and other developed countries since the 40s of the $20^{\text {th }}$ century. They also show how effectively Russia combines the offensive nature of its propaganda with the latest information technologies (including "innovations" in the field of manipulation). B. Franklin and M. Carlson (2011) reveal how effectively manipulation of information contributes to the manipulation of mass consciousness. S. Macdonald (2007) explores the ability of falsification (or partial falsification) of video documentation to hide and distort the real, factual basis of media reports. This feature of video communication is effectively used by Putin's propaganda recently. However, simply exposing the fakes of Putin's propaganda (including those created with the help of false documentation) is not enough. It is important to create documentary that meets the strong ethical and aesthetic standards of video communication in addition. A similar conclusion can be made regarding the article by the 
authors' group which emphasizes the importance of video communication in enhancing the emotional reactions of an audience (Shamsiah Abd Kadir et al., 2016).

According to D. Miller (2004), the key to understanding propaganda strategies is media dominance. F. Zollmann (2019) convincingly illustrates how various forms of propaganda can appear in news media content and aims at developing tools for the identification of propaganda in media. $R$. Ottosen (2009) analyses the role of video games in constructing propaganda messages and concludes that effectiveness of this form of influence on the audience (especially the young one) in the ideological struggle has been clearly underestimated so far. M. Soules (2015) explores a phenomenon of persuasiveness of propaganda and advertising messages. S. Woolley and P. Howard (2016) reveal the danger of using modern computer algorithms to "automate" the creation and distribution of content in a modern digital environment. This danger stems not only from the dishonesty of the communicator, but also from the fundamental inability to control these processes, which the result of the very nature of automated self-programming. The authors do not analyze specific political and ideological consequences of this process, however, the practice of Putin's agents and their activity on social networks shows that these latest achievements in computer technology are also successfully used in "hybrid warfare".

These and other publications are dealing with the phenomenon of Putin's propaganda as a harsh violation of objectivity standards and access towards information. Yet, this article aims at providing alternative approach towards organizing mass communication systems designed to change the situation both in Russia and the whole post-Soviet area and claims that there are other no less effective than purely "military" methods of successful opposing Putin's propaganda both in Russia and abroad. Therefore, the article starts with the analysis of the transformation of "Soviet idea" into "Russian idea" and the KGB concept "active measures". Then specifics of modern Russian media and its role in "hybrid warfare" are revealed. Finally, possible approaches in dealing with Russian propaganda are discussed. In order to achieve the goal, we use methods of qualitative literature and other data analysis, systematizing and critical approach. It is important to note that some definitions used in this article 
and marked with quotation marks are translations of historically formed Russian discourse or slang expressions that are common for modern communication as well as for Putin's propaganda and has no scientific equivalent: "post-truth", "active measures ", "strong hand", "trolls" etc. However, their usage is unavoidable in this problematic field.

\section{From "Soviet idea" towards "Russian idea": transformation of Soviet "active measures" in Russian communication}

Offensive and aggressive communication practices of modern Russia are rooted in Soviet propaganda which has derived from Stalin's and Lenin's propaganda accordingly. In addition, many authors use the concepts Russian propaganda and Putin's propaganda synonymously (e.g. Van Herpen 2016). In this context, one of the key concepts of Russian communication is "active measures", which in the terminology of the KGB as the main institution for implementing this policy in times of USSR, the term "active measures" meant extremely dynamic, aggressive actions of the widest range of impacts aimed at achieving the goal by any means, including the most extreme ones (Abrams 2016).

This term was rapidly filled with new content by Putin's team which realized that freedom of speech, access to information as well as expansion of international exchange and open borders evolved over the 15-year period (1985-2000) are disastrous for the authoritarian regime and therefore, it is necessary to create new algorithms for managing the population of a huge country with the help of information technologies. To this purpose, in the early 2000s and in subsequent years an internal transformation of the information space of Russia took place: free media was replaced by a well-coordinated and efficient state mechanism directed towards ideological treatment of the population. The information space became more and more manipulative, deliberately focused on the low-quality entertainment of the population. At the same time, the collapse of the Soviet Union was publicly assessed as the largest geopolitical catastrophe of the $20^{\text {th }}$ century, as a time of "humiliation" of the Russian people and the "trampling" of the foundations of Russian statehood. Complicated Post-Soviet reality was presented as a reward for the collapse of the "ideals of justice" (e.g. Demurin 2019). Thus, the "Soviet idea" was replaced by "Russian idea" inviting millions of people 
inside and outside of Russia to "return the former greatness of the "Russian spirit" and Russian patriotism is considered as the only answer to the challenges of globalisation. Examples of these ideologies could also be found in the materials of the international conference held by the Russian Institute for Strategic Studies (2014) and other publications of this institute, which is one of the leading think tanks for the formation of Putin's internal and foreign policies. Numerous publications on this subject create a discourse in which such statements become official. As a result, archaic forms of the Russian mentality and lifestyle reproduced the craving for a "strong hand", "strong State" in Russia and Russian diaspora. (Uroven odobrenia Stalina rossianami pobil istoricheskie record, 2019).

The interest of researchers of mass communications in what is understood by the "Russian idea" as the basic concept of Putin's propaganda is symptomatic. For instance, P. Panov analyzed the texts of all annual presidential messages from Yeltsin to Putin (including a short period of Medvedev's presidency) and came to a conclusion that there have been significant changes in this ideological field over the years. The concept of "Russians" has come to the forefront and is understood not as "Russian people" or "Russian citizens" but as adherents of the Russian "idea", Russian culture, and state patriotism, the idea of a strong and great Russia as well as the uniqueness of Russian civilization. This creates connotations in which all the Russian speakers can be considered "Russians", regardless the place they live, or even not Russian speakers, but influenced by these stereotypes (Panov 2010).

The war in Georgia, the invasion into Eastern Ukraine, the "annexation" of Crimea revived the chauvinistic and imperial sentiments of a significant part of the Russian population. The events in Ukraine immediately raised the ratings of Russian television channels, as for Putin's ratings - they increased to $86 \%$ (The Guardian 2015). A significant part of the Russian population still believes in the idea of a kind of "Russian exclusivity", the "special mission" of the Russian people, designed to create their own "Russian world" on a geopolitical scale (Nastoyashchee vremia 2016; Novye izvestiya 2018). However, it is important to remember that such psychological phenomena arise from archetypes that are directly opposite, which are the awareness of the 
futility of the lifestyle, either imposed "from above", or chosen by the individual himself. As a result, external military "successes" play the role of a psychological compensator for subconscious and depressive, in fact, massive psychological processes (Mochar 2019; Bershidsky 2019).

Therefore, Putin's external expansionist actions are aimed to divert attention from internal problems, which fail to be solved. At some point, the external expansionist policy as a whole as well as the "hybrid warfare" as one of its instruments has substituted goals of domestic and foreign policy: instead of actual reform of Russian economy and social sphere, Putin's administration is trying to stabilize the domestic political situation and the international image of Russia not by changing reality, but by creating images in and of itself, or, in J. Baudrillard's words, simulacra. The phenomenon of "post-truth" attributed to Putin's propaganda gives an invaluable advantage for the government: a) the narrative does not need to correspond to the reality; b) any stereotypes can be fixed regardless of whether they correspond to facts, personal experience of millions of information recipients (Starikevich 2019). Thus, incapability of Putin's propaganda to hide the gaps of socio-economic development is artfully fixed by media according to a well-known principle: "Attack is the best form of defence". For this purpose, the repressive directions of domestic politics and the strengthening of the anti-Western (especially anti-American) rhetoric in Russian state media is used. As it is noted in the Freedom House report (Contending with Putin's Russia 2013), starting in 2012 (Putin's return to the presidency), "step by step, Putin has pushed through measures to deter public demonstrations, smear and limit funding for nongovernmental organizations, and place restrictions on the internet. He has also made anti-Americanism a central part of his political message. He has accused the United States of fomenting demonstrations against election fraud, shut down all U.S. Agency for International Development (USAID) programs in Russia, withdrawn from a series of cooperative agreements with the United States, and signed a vindictive law that prohibits the adoption of Russian children by citizens of the United States" (p. 2).

At the same time, the authorities of modern Russia respond to numerous crisis situations in the spirit of "soft" authoritarianism. That is, desiring to maintain control avoiding direct repression. This is achieved 
mainly by replacing the delinquent officials. The very "highest official", supposedly, remains outside the zone of public discontent and protest. In the most serious cases, the communicative arsenal of authoritarian power is turned on at full power, and the proper result is achieved by massive application of administrative and informational measures. One of the most demonstrative examples is Putin's address to the Russian population in August 2018 regarding the change in pension legislation. In this particular (and many other) cases, the mass protest sentiments were extinguished, however, such methods, according to researchers, carry the risk of systemic disruption in the most unexpected way. The approach of such a systemic disruption is evidenced by recent surveys of Russian sociologists. According to a survey of the Russia Public Opinion Research Center, the Putin confidence index fell from 45 to 25 percent within a year (from May 2018 to May 2019). Only less than a third of Russians trust the solution of important state issues to the president. This is a record low mark for his entire time in power (DW 2019). According to the July (2019) data of the joint study of the Carnegie Moscow Center and the Levada Center, $53 \%$ of Russians are in favour of radical changes in the political system, and $34 \%$ agree to changes while maintaining the existing system. At the same time, the percentage of those who believe that Putin is able to offer an attractive plan for transformation has decreased by $9 \%$ (from $25 \%$ to $16 \%$ ) (Vedomosty 2019). These figures testify not so much to the crisis of the "Russian idea" as to social protest caused by a sharp deterioration in the material situation of the population. At the same time, they indicate not only increase in critical attitude in society, but also a broad social demand for other forms of communication between the authorities and the population. It might be the space in which the creation of new information systems, alternative to those existing in Russia, is possible.

\section{Specifics of modern Russian media and its role in a "hybrid warfare"}

Leading Russian developers of concepts of modern warfare rely on the premise that the "hybrid warfare" that have already begun are "wars of meanings", and their ultimate goal is "conquering the future" (Vladimirov 2015: 3). Therefore, the main area of hostilities is the information space, where it is necessary to gain a dominant position in order to achieve 
military superiority (Shcipicyn and Shcipicyna 2018). In this a paradigm media and information technology play a key role.

In this context, two media strategies (for domestic and foreign purposes) where designed. The domestic strategy aimed at suppression of dissenting media and ensurance the dominance of state-owned media, as well as private media loyal to the Kremlin. Thus, with the beginning of Putin's presidency the elimination of free media that did not meet their "military" mission has started: attacks on journalists, editorial offices and television centers; censorship; criminal prosecution of journalists, media and bloggers; dismissal of journalists and editors; police detentions; threats against journalists, editorial boards and bloggers; denial of access to information; termination of the media outlet and disconnection from the air; seizures and arrests of editions; damage to equipment and computers, etc. The systematic nature of the repressions aimed at putting the media at the service of the Putin regime is evidenced by the long-term monitoring of the Glasnost Defense Foundation (http://www.gdf.ru/monitoring). This situation allowed independent Russian researchers to point out these features of Russian state policy in the field of mass media:

- lack of an officially proclaimed and universally recognized national strategy of information development;

- pluralism and independence of media are not a priority of state policy. Media is considered solely as an administrative resource for power retaining;

- citizens' access to information about the activities of state bodies does not contribute to the sustainable socio-economic development of Russia. On the contrary, it strengthens the negative attitude of citizens towards these institutions (Nisnevich 2007).

All subsequent years confirmed these conclusions, except for one: the strategy of development of the Russian media existed and still exists. However, instead of aiming at such ideals as media pluralism and independence, it is directed towards transformation of media into a reliable and effective mean of manipulating the public opinion in Russia.

In addition, during the period of 2000-2020 Putin's propaganda has diverted the attention of the Russian population from their own problems towards "denouncing" of the Western way of life by granting infernal 
character to almost any foreign material and thus forming a stable image of the enemy (Deutschlandfunk 2016). At the same time, media strategies intended to influence external audiences including foreign Russianspeakers were elaborated. Here, "...Putin positions himself as a renegade abroad, deploying the hyper-modern, reflexively contrarian RT - an international news agency formerly known as Russia Today - to shatter the West's monopoly on "truth." (Dougherty 2015). Thus, in 20 years Russian media became a weapon in information war and denied its original mission to serve as a reliable source of objective information, education and the dissemination of humanist values. In order to influence domestic and foreign audiences various means are applied. C. Paul, and M. Matthews (2016) distinguish these features of the contemporary model of Russian propaganda: a. high-volume and multichannel (variety of sources; number and volume of sources; the views of others, especially the views of those who are similar to the message recipient); b. rapid, continuous, and repetitive (first impressions are very resilient; repetition leads to familiarity, and familiarity leads to acceptance); c. lacks commitment to objective reality and consistency (p. 2-8).

The analysis of Russian broadcasting also reveals the dominance of "entertainment" (Adindex.ru 2017). On the one hand, TV-series, shows and programs give to viewers (both Russian and foreign) a break from the hectic daily life. On the other hand, they still complete a well-defined propaganda task (Tolz and Chatterje-Dooddy 2018). It is important to note that the content and plots of numerous military-police TV-series stress the fortress of the "Russian character", the ability to solve all problems (mainly by force), and loyalty to the "ideals" of the current Russian state. The production of numerous, "militaristically" infected video games and even cartoons for children of a very specific, "military-patriotic" theme can be added to this (Luzin 2019).

The latest information technology tools allowed effective application of traditional methods of brainwashing. The ability of social networks of "self-manipulation" due to the anonymity of sources, massive information dumps, etc., turned to be a godsend for specialists in "hybrid warfare". This is very well mastered and has been put on an industrial basis: "troll factories" is a purely Russian invention. These actions have an aggressive-manipulative and often direct subversive character (Osipova 
and Byrd 2017). The example of the centrally organized activity of numerous "trolls", activated on social networks in quite specific thematic areas, is the evidence of a psychological war of the Russian authorities against their own population. These and many other innovations are successfully used to introduce new ideologies. The global trend of the politicization of media and the medialization of politics (i.e. media hybridization) took such a form in Russian reality (Chadwic 2017). These strategies and tactics are also applied in times of Covid-19 pandemic which has become another occasion for new information and sabotage operations of Russian propaganda services, aimed at both inciting hatred of the international community in Russian society and misleading foreign audiences (Broad 2020; Rankin 2020).

Also, in recent years Putin's propaganda has acquired new, highquality characteristics that make it an even more effective weapon in hybrid warfare. First of all, we can notice an increased departure from severely restricting access to information. Politically sensitive issues and even criticism of the regime are allowed in resources that are far from being as widespread as government officials. Of course, such phenomena cannot be called "freedom of speech," but for some segments of the Russian audience they serve as a sign of "objectivity" and "reliability," thereby the stability of the status quo. Thus, without essentially changing the general bias of the Russian media, such approaches limit the tough critics of the regime - both in the country and abroad. Secondly, the propaganda services of Russia are developing more and more successfully on a new technological base: multimedia platforms, social networks, instant messengers, chats, etc. In terms of content, they have learned to use Western media miscalculations well and often return their own invectives to them, but in the form of "special operations", which allegedly testify to worldwide "conspiracy" against Russia and "antiRussian hysteria" (Tolz and Chatterje-Dooddy 2018). All this helps Putin's propagandists not only to zombie their own citizens, but also to recruit supporters among certain segments of the population in the West. Thus, as V. Tolz and P. N. Chatterje-Dooddy (2018) notice, "Contemporary liberal democracies remain largely in the dark about the complexities of Russia's media operations - and this leaves them ill-prepared to respond to the media manipulation strategies". 


\section{Dealing with Russian propaganda: from militaristic towards value- based approach}

Taking into account the increasing sophistication of Putin's propaganda services, one cannot help but come to the conclusion that the paradigm of counteraction to these tactics of hybrid warfare, adopted by the Western world, needs to be changed. According to V. Veebell and R. Markus (2016), "militaristic" methods, accumulated during the Cold War and welldeveloped nowadays are able to restrain Russian ideological expansion, but limited. Direct pursuit of purely "military" goals leads to a strong temptation to respond to Putin's propaganda in the same manner that is exercised by giants of the Russian communications industry (RT, Sputnik, Russia Today Agency, etc.). However, such forms of communication do not provide long-term effects as the collapse of the purely "apparatus", top-level structures of the Russian government will not bring crucial changes, just as the destruction of the Soviet governing bodies in 1991 brought nothing new. Instead, the most urgent task here is to choose the field of possible influence on Russian media, i.e. the information component of socio-political processes in this country. In other words, it is necessary to create new directions of the world media activity, based on material collected from various fields and levels of Russian reality. For this purpose, Russian public consciousness can be used not fighting against a strong influence of well-known prejudices, but relying on them because this is the gateway to the Russian audience.

If certain archaic psychological stereotypes inherent in Russians and Russian-speaking population allow Russian media to keep status quo, then it is important to find ways of destruction, or, more, precisely, replacement of such stereotypes by other ideas which could become the ideological basis for possible changes. "Achilles heel" of Putin's propaganda is "simulacra" built on ideological stereotypes that are not related to Russian reality. Therefore, the main area of activity of the world media may be broad (including Russian) multidirectional information about the real economic and social situation in Russia as well as the moral and psychological state of its population. A significant role here can be played by the transformation of applied scientific knowledge into actual communicative, informational society (Kornienko et al. 2015). Such 
scientific and practical concepts as the rule of law, civil society, private property and entrepreneurship, public self-government, etc. can be the basis. However, they should be based on deeper, existential concepts keeping in mind specifics of Russian Protestant mind-set, directed against the external "enemies" of Russia. Therefore, a transformation of humanistic, philosophical, sociological knowledge into the mass media information cannot be realized straightforward. Instead, the main methods of content preparation can be the utmost depoliticized, strictly documentary, detailed, systematic study of the most important socioeconomic processes in Russia and the transmission of this information to mass contingents of TV-viewers, radio listeners and Internet users of the Russian Federation, Europe and the whole world. Specific tools for this are contained in the CEPA recommendations (2017). Particular attention should be paid to regional news in Russia since local news and events are closer to the recipient's personal experience and therefore, they reach their audience in the most effective way. In other words, communication with the Russian population should be built on universal values, the realities of life, lifestyle and spiritual unity of people.

Yet, it does not mean that this approach will be easily accepted by Russian audience. Therefore, there is a need of long-term, gradual and well-elaborated strategies and tactics of mass communication as well as conceptual analysis of the genesis of various phenomena in Russian history, lifestyle, daily life, habits and addictions since all of them contributed to the formation of system of power that has been ruling in Russia for almost twenty years. Any other way, for example the desire to "unmask" Putin's regime, is counterproductive and leads towards the opposite result: strengthening the stereotypes of "great power", "greatness" of the "Russian world", and the "special mission" of the Russian people. In other words, only different forms of Russian culture can be opposed to mass culture replicated by Putin's media.

It is important to note, that humanistic principles can already be found in Russian culture (including mass culture as well): in rich traditions of folk and professional musical creativity, cultural and social initiatives aimed at solving regional and local problems, the expansion of selfgovernment practices in various fields of daily life, and growing public 
discontent. However, they are proclaimed only by peripheral Russian media and are not accessible for the majority of the Russian population.

On the other hand, modern information technologies provide with the number of other opportunities that are not indifferent to their content: various forms of interactivity, direct relation between audience and a communicator are already changing the information landscape, opening up the possibilities of "information democracy", creating alternative social networks that are aimed at the personal involvement of Russian citizens in information campaigns. Good example is YouTube video content created by the representatives of Russian civil society (independent journalists, television reporters, video bloggers, and ordinary citizens) which reflects the reality in regions of Russia. Some of these materials were created with the support of state and non-state structures of the Russian Federation in order to capture the ethnographic realities of the life of the country (for example, the series of video reports "Happy People" was created with the support of the Russian Geographical Society). However, the reliability and visibility of these materials carries a clear ideological component, even more valuable because it arises spontaneously, sometimes against the will of the authors. Russia tells about itself objectively and visually. This story reveals the fact of allogeneity of the current regime to the realities of life, mentality, lifestyle of millions of Russians better than all ideological actions. Some of these materials have millions of views, and these are not "forced" views of nationwide television channels, speculative and deceitful. They are especially valuable because they were created in Russia itself, without any external interference or influence. The only task is to give them the appropriate sound, creating high-quality media products based on them that would enable these videos to be seen by the majority of Russian viewers. Here the question of quantity becomes a question of a different quality of social communication. Consequently, there are some means needed for the targeted delivery of this content to Russian, as well as all Russian-speaking audiences.

Therefore, it is important both the expansion of the scope of existing media and creation of new forms of quality media that could operate both inside and outside of Russia. The basis of alternative information systems that undermine the foundations of the current authoritarian Russian 
government can be an appeal to basic humanitarian values as the only alternative to the development of democratic Russia. If we recognize the objective value and effectiveness of those psychological mechanisms that contribute to Putin's propaganda, then why can't the same mechanisms work against it?

\section{Conclusions}

The years preceding Putin's rise to power were a kind of "Renaissance" for Russian media. Communist slogans and stereotypes were rapidly supplanted and replaced by global standards for objective and reliable public information. However, the situation has roughly been changed by Putin's administration. The "Soviet idea" was replaced by the idea of the "Russian idea", for the propagation of which, inside and outside the country, openly forceful, repressive methods were applied. The stateowned Russian media and private media, fulfilling the will of the authorities, become a weapon in the hybrid warfare. The most modern technical and technological means are used, which serve, however, the purposes of manipulating the public consciousness both inside Russia and abroad. The exploitation of the archetypal ideas of the Russian population about the "strong hand" inside the country and the "rotten West" outside it brought certain results, namely: distracting the attention of the population from its own, extremely acute socio-political problems.

Stereotypes of Putin's propaganda cannot be eradicated by purely "military", "counter-propaganda" methods. The Russian people should not be considered as an active subject of Putin's propaganda, but rather as its recipients and even victims. Therefore, it is necessary to break the vicious identity of both Russian mentality and Russian government. Thus, instead of focusing the influence on a Russian-speaking audience on the values of the external, "civilized" world, it is necessary to present the reality of Russian life because mass audience can assimilate such terms as "democracy", "civil society", "tolerance", etc. only through live examples, which involve personal experience. Therefore, it is important to develop constructive psychological stereotypes in order to disseminate the Western values and encourage critical thinking as well as to use the diverse capabilities of modern technologies, tools and services of social 
networks, computer program algorithms etc. New forms of communications can also be built by adequate and sound practices that already exist in Russia, e.g. alternative forms of artistic culture, diverse manifestations of "grass-root" artistic creation, personal and social initiatives, actions and movements. In addition to various opportunities for creating alternative high-quality media, it is equally important to emphasize the scope of their activities. In case of Putin's propaganda, quantity often substitutes quality as falsification is capable only of hiding and not of changing reality.

The necessity of a radical reframing of traditional approaches to the ideological (communication) components of hybrid warfare imposed on the West by the ideological institutions of Putin's administration does not minimize the importance of direct opposition. Military metaphoric can still be used where appropriate. However, the long-term task is the formation of mass consciousness in accordance with the standards of the information society. Based on these principles, it is quite possible to develop strategic and tactical areas of communication in the information field of Russia to the extent of the topic, focus, methods of preparing journalistic and analytical materials as well as the ways of their delivery to the target audience.

\section{References}

Abd Kadir, Shamsiah, Mohd Lokman, Anitawati, and Tsuchiya, T, (2016). Emotion and techniques of propaganda in youtube videos. Indian Journal of Science and Technology, 9(1), 1-8. Available from: http://www.indjst.org/index.php/indjst/article/view/106841

Abrams, Steve (2016). Beyond propaganda: Soviet active measures in Putin's Russia. Connections: The Quarterly Journal, 15(1), 5-31. Available from: http://dx.doi.org/10.11610/Connections.15.1.01.

Aktas, H. (2017). Taxonomy of hybrid warfare: A perceptional analysis. Available from: https://www.behorizon.org/taxonomy-of-hybrid-warfare/. [22 September 2017].

Vedomosty (2019). Almost 60\% of Russians favor decisive changes in the country. Available from: https://www.vedomosti.ru/politics/articles/2019/11/05/815494-pochti-60-rossiyan 
Cockburn, A. (1974). The first law of journalism: To confirm existing prejudice, rather than contradict it. Quote n.d., A-Z Quotes. Available from: https://www.azquotes.com/quote/609531.

Bershidsky, L. (2019). Putin ne smog vernut lubov Rossii. Inosmi.ru 21.12.2019. Available from: https://inosmi.ru/politic/20191221/246458988.html

Broad, W. (2020). Putin's long war against American science NYT, Available from: https://www.nytimes.com/2020/04/13/science/putin-russiadisinformation-health-coronavirus.html

Center for European Policy Analysis, (2017, April). Winning the information war redux: Techniques and counterstrategies to Russian Propaganda in Central and Eastern Europe. Available from: https://docs.wixstatic.com/ugd/644196 264a764d8fc04714a883355f4a c682b9.pdf.

Chadwick, A. (2017). The hybrid media system: politics and power. Second Edition. Oxford University Press, New York, NY. Available from: https://www.andrewchadwick.com/hybrid-media-system-secondedition

Freedom House (2013). Contending with Putin's Russia: A Call for American Leadership. 06.02.2013. Available from: https://freedomhouse.org/sites/default/files/2020-02/SR Contending with Putins Russia PDF.pdf

Demurin, M. (2019) Raspad SSSR: Pochemu eto katastrofa I pochemu ne "blagoslovenie. [The collapse of the USSR: why is it a disaster and why is not a "blessing"] Available from: https://regnum.ru/news/polit/2664404.html ; "V RAN proschitali scenarii raspada Rossii" [The RAS calculated the collapse of Russia]. Ex-Press, 04.12.2019 Available from: $\quad$ https://ex-press.by/rubrics/v-mire/2019/12/04/v-ranproschitali-scenarii-raspada-rossii

Dougherty, J. (2015). How the media became one of Putin's most powerful weapons. The Atlantic, 21 April 2015 Available from: https://www.theatlantic.com/international/archive/2015/04/how-themedia-became-putins-most-powerful-weapon/391062/.

Franklin, B. and Carlson, M. (eds) (2011). Journalists, sources and credibility: New perspectives. New York: Routledge.

Haridakis, P., Hugenberg, B. and Wearden, S. (2009). War and the media: Essays on news reporting, propaganda and popular culture. McFarland, Jefferson, N.C. Available at: https://www.worldcat.org/title/war-and-the- 
media-essays-on-news-reporting-propaganda-and-popularculture/oclc/386706606.

Kornienko, A., Kornienko, A., Fofanov, O. and Chubik, M., (2015). The nature of knowledge power in communicative information Society, Procedia. Social and Behavioral Sciences, 166, 595-600. Available from: https://doi.org/10.1016/j.sbspro.2014.12.579.

Novye izvestiya (2018). Lenin byl prav: russkije vedut sebia kak shovinisty [Lenin was right: Russians are acting like chauvinists] Novye izvestiya, 05 June 2018. Available from: https://newizv.ru/news/society/05-062018/lenin-byl-prav-russkie-vedut-sebya-kak-shovinisty.

Nastoyashchee vremia (2016). Levada: tret' rossijan - za to, chtoby ne puskat'v stranu kavkazcev i zhitelej Central'noj Azii [Levada: third of Russians are in favour of not accepting Caucasians and residents of Central Asia] 2016, Nastoyashchee vremia, 11 October 2016. Available from: https://www.currenttime.tv/a/28045092.html.

Luzin, P. (2019). How successful is Russia's military propaganda media? The Moscow Times 10.07.2019. Available from: https://www.themoscowtimes.com/2019/07/10/how-successfulrussias-military-propaganda-media-a66337

Macdonald, S. (2007). Propaganda and information warfare in the twenty-first century: altered images and deception operations. Routledge, London; New York. Available at: https://www.psywar.org/macdonald.php

Magda, Y. (2015). Hibrid war: Survive and win. Vivat Publishing, Kharkiv, 10.

Miller, D. (2004). Information dominance: The philosophy of total propaganda control? In War and the Media: Essays on News Reporting, Propaganda: A Global Perspective. Rowman \& Littlefield Publishers, inc. Oxford, UK, 7-10. Available from: https://rowman.com/ISBN/9781461646846/War-Media-and-Propaganda-A-Global-Perspective

Mochar, K. (2019). Strategia Putina - vnutrennye problem Rossii reshaem cherez vneshnye [Putin Strategy - Russian Internal problems are solved though external]. Irex.ru, 29.10.2019. Available from: https://iarex.ru/articles/71934.html

Nagy, P. M. , (2000). The meltdown of the Russian state: The deformation and collapse of the state in Russia. Edward Elgar Pub, Cheltenham, UK; Northampton, MA. Available from: https://books.google.by/book-

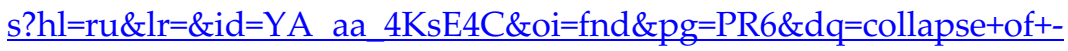
the+Russian+Statehood\&ots=U_GnhMkspG\&sig=0oupYSqsGuqHG 
k43ziQWqZ6ix0w\&redir esc $=y \# \mathrm{v}=$ onepage\&q=collapse $\% 20$ of $\% 20$ th e\%20Russian\%20Statehood\&f=false

Nardelli, A., Rankin, J. and Arnett, G.(2015). Vladimir Putin's approval rating at record levels. The Guardian, 23 July 2015. Available from: https://www.theguardian.com/world/datablog/2015/jul/23/vladimirputins-approval-rating-at-record-levels

Deutschlandfunk (2016). Nemeckij politik: "Obraz vraga nuzen Kremliu, chtoby otvlech rossian ot problem [German politician: Kremlin needs "Image of the Enemy" to distract Russians from problems]. Deutschlandfunk, 07.10. 2016. Available from: https://russian.rt.com/inotv/2016-1007/Nemeckij-politik-Obraz-vraga-nuzhen

Nisnevich, Y (2007). Problemy gosudarstvennoj informacionnoj politiki Rossii $\mathrm{v}$ uslovijah postindustrial'nogo razvitija [Problems of the state information policy of Russia in the conditions of post-industrial development] in Rossija: tendentsii i perspektivy razvitija [Russia: trends and perspectives of development]. Vypusk 2, pp. 241-243. INION RAN, Moskva. Available from: .https://publications.hse.ru/chapters $/ 68171600$

Oates, S. (2016). Russian media in the digital age: Propaganda Rewired, Russian Politics, 1(4), 398-417. Available from: https://doi.org/10.1163/2451-8921-00104004.

Odobreniye institutov vlasti (2019, 05 July). [Approval of government institutions] Available from: https://www.levada.ru/2019/07/05/odobrenie-institutov-vlasti-14/.

Osipova, N. and Byrd, A. (2017). Inside Russia's network of bots and tpoll. The NY Times, 31.10.2017. Available from: https://www.nytimes.com/video/us/politics/100000005414346/howrussian-bots-and-trolls-invade-our-lives-andelections.html?smid=pl-share

Ottosen, R., (2009). Video games as war propaganda: Can peace journalism

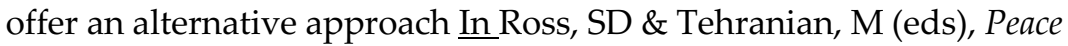
journalism in times of war, pp. 93-110. Transaction Publishers, New Brunswick (U.S.A.).

Panov, P. (2010). Nation-Building in Post-Soviet Russia: What kind of nationalism is produced by the Kremlin?. Journal of Eurasian Studies, 1(2), 85-94. Available from: https://doi.org/10.1016/j.euras.2010.04.001. 
RISS (2014). Patriotism kak ideologia vozrozdenia Rossii: sbornik statej I dokladov [Patriotism as an ideology of the revival of Russia: compilation of articles and reports]. M.:RISS, 2014, 9; 11; 27. Available from: https://riss.ru/wp-content/uploads/2016/02/Patriot. ves-tekst.pdf

Paul, C. and Matthews, M. (2016). The Russian 'Firehose of Falsehood' propaganda model: Why it might work and options to counter it. RAND Corporation. Available from: http://www.rand.org/pubs/perspectives/PE198.html.

Rankin, J. (2020). Russian media 'spreading Covid-19 disinformation. Guardian, 18.03.2020. Available from: https://www.theguardian.com/world/2020/mar/18/russian-mediaspreading-covid-19-disinformation

DW (2019). Reiting doverija Putinu dostig rekordno nizkogo urovnia [Putin's confidence rating reaches record low], DW, 25.05.2019, DW.COM. Available from: https://www.dw.com/ru/рейтинг-доверия-путинудостиг-рекордно-низкого-уровня/а-48874105

Shamsiah, A. K., Anitawati, M. L. and Toshio, T. (2016). Emotion and Techniques of Propaganda in YouTube Videos. Indian Journal of Science and Technology, 9(S1), December 2016. Available at: https://pdfs.semanticscholar.org/7996/273d350adef8105287dbce0584 e340e9022f.pdf

Shcipicyn J.B., Shcipicyna A.J. (2018). Gibridnaja" vojna: modelirovanie informacionnyh polej ["Gibrid Warfare: Information Fields Modeling]. Ekaterinburg.

Sluzba monitoringa Fonda zashchity glasnosti. Available from: http://www.gdf.ru/monitoring

Soules, M. (2015). Media, persuasion and propaganda. Media topics. Edinburgh: Edinburgh University Press.

Starikevich A. (2019). Tsunami dezinformatsii: kak otvechaet Zapad - Salidarnasć [Tsunami of disinformation: how the West responds]" - Salidarnosc, 05 December 2019. Available from: https://gazetaby.com/post/czunamidezinformacii-kak-otvechaet-zapad/158801/.

Sussman, G.(2011). The propaganda society: Promotional culture and politics in global context. Peter Lang, New York. Available from: https://www.amazon.com/Propaganda-Society-PromotionalFrontiers-Communication/dp/1433109964 
AdIndex.ru (2017). Tendentsii rossijskogo teleefira [Trends in Russian television] 10 October 2017, Available from: https://adindex.ru/publication/analitics/channels/2017/10/10/166352.phtml.

Tolz, V., and Chatterje-Dooddy, P.(2018). Four things you need to know about Russian media manipulation. Available from: https://theconversation.com/four-things-you-need-to-know-aboutrussian-media-manipulation-strategies-94307

Rbc.ru (2019). Uroven odobrenia Stalina rossianami pobil istoricheskie record. [The level of approval of Stalin by Russians broke a historical record]. rbc.ru, 16.04.2019. Aviable at: https://www.rbc.ru/politics/16/04/2019/5cb0bb979a794780a4592d0c

Veebel, V. and Markus, R. (2016). Will sanctions against Russia be successful: will Russia fall before Ukraine? Journal of security and Sustainability Issues, 5(4), 465-480. Available from: https://doi.org/10.9770/jssi.2016.5.4(1).

Van Herpen, M. (2016). Putin's Propahanda Machine. Soft Power and Russian Foreign Policy. Rowman \& Littlefield, London-NY, 2016, 1.

Vladimirov A. (2015). Gibridnye vojny v obscchej teorii vojny. Russian Ministry of Defense, 28.01.2015, 3. Available from: http://kadet.ru.skyline.mtw.ru/lichno/vlad v/Gibridn voiny VUMO RF_28.012015.pdf

Haridakis, P. M., Hugenberg, B., S. and Wearden, S.T. (2009). War and the Media: Essays on News Reporting, Propaganda and Popular Culture. McFarland \& Company, inc., publishers. SA.

Kamalipour, Y. R. (2004). War, Media, and Propaganda. A Global Perspective. Oxford, UK, 2004.

Woolley, S. and Howard, P. (2016). Automation, algorithms, and politics I political communication, computational propaganda, and autonomous agents - introduction, International Journal of Communication, 10, 4882-4890. Available from: https://ijoc.org/index.php/ijoc/article/view/6298/1809

Zollmann, F. (2019). Bringing propaganda back into news media studies. Critical Sociology, 45(3), 329-345. Available from: https://doi.org/10.1177/0896920517731134. 


\section{Kaynakça Bilgisi / Citation Information}

Melnikau, E. (2021). Towards transformation of communication strategy in dealing with Russian propaganda. OPUS-International Journal of Society Researches, 18(40), 727-749. DOI: 10.26466/opus.783555. 